A

$\mathrm{N}$

\title{
Sesja naukowa pt. Klauzula sumienia, Warszawa, 20 lutego 2014 r.
}

W dniu 20 lutego 2014 r. w siedzibie Sekretariatu Konferencji Episkopatu Polski w Warszawie odbyła się sesja naukowa pt. Klauzula sumienia. Konferencja została zorganizowana przez Katolicką Agencję Informacyjną i była połączona z prezentacją „Stanowiska Zespołu Ekspertów Konferencji Episkopatu Polski ds. Bioetycznych w sprawie klauzuli sumienia”.

Program Sesji składał się z dwóch części. Obrady zainaugurował, witając wszystkich uczestników, pan Marcin Przeciszewski, redaktor naczelny i prezes zarządu KAI. Następnie słowo wstępne wygłosił bp Wojciech Polak, sekretarz Generalny Konferencji Episkopatu Polski. W swoim wystąpieniu ukazał problematykę zorganizowanej sesji naukowej i jej aktualność w związku z odpowiedzią Zespołu Ekspertów Konferencji Episkopatu Polski ds. Bioetycznych na wydane w dniu 12 listopada 2013 r. stanowisko Komitetu Bioetycznego przy Prezydium PAN w sprawie tzw. klauzuli sumienia ( $\mathrm{nr} 4 / 2013)$.

Pierwszy referat, pt. Sprzeciw sumienia, prawem i obowiąkiem chrześcijanina - obywatela, wygłosił abp Henryk Hoser, biskup warszawsko-praski, przewodniczący Zespołu Ekspertów ds. Bioetycznych przy KEP. Prelegent w swoim wystąpieniu podjął próbę ukazania fundamentów w definiowaniu pojęcia sumienia. Sumienie swoją podstawę winno mieć zawsze w godności człowieka (miara wartości jaką przypisujemy człowiekowi i wartość niezbywalna) oraz w jego wolności. Godność i wolność człowieka jest zagwarantowana w legislacji międzynarodowej (np. w Karcie Narodów Zjednoczonych - art. 1, 18; w Powszechnej Deklaracji Praw Człowieka). W swoim wystąpieniu ukazał także wyższość prawa moralnego nad prawem stanowionym.

Ks. prof. Ireneusz Mroczkowski, były przewodniczący Stowarzyszenia Teologów Moralistów, kierownik Katedry Antropologii i Bioetyki 
na UKSW w Warszawie, w referacie pt. Klauzula sumienia $w$ nauczaniu moralnym Kościoła odwołał się do Stanowiska Komitetu Bioetycznego przy Prezydium PAN z 2013 r. i uzasadnił, że w/w stanowisko nie zawiera nawet próby definicji sumienia, a ponadto brak w nim dyskursu typowo etycznego. Sumienie definiował jako zdolność intelektualnego poznania do oceny i kierowania swoim postępowaniem; oceny, czy jest się dobrym człowiekiem. Ukazując nauczanie moralne Kościoła przy powołaniu się na stanowiska jego przedstawicieli stwierdził, że Kościół broni sumienia dobrze ukształtowanego. Sumienie jest zawsze stróżem, świadkiem i sędzią każdego człowieka. Odpowiadając na zadane w swoim przedłożeniu pytanie: co można powiedzieć o sumieniu, jeśli czyta się Freuda, Marksa, czy Nietzsche' go? podjął się próby ukazania fundamentów sumienia chrześcijańskiego.

Referat prof. Zbigniewa Cieślaka (UKSW), sędziego Trybunału Konstytucyjnego, pt. Klauzula sumienia we współczesnych systemach prawnych, dotyczył analizy aktów prawnych, które stanowią podstawę do właściwego rozumienia powoływania się na klauzulę sumienia. Prelegent stwierdził, że nie ma definicji sumienia w prawie. Odnosząc się do rodzajów sumienia wymienił m.in. sumienie przed-uczynkowe i sumienie po-uczynkowe. Ten pierwszy rodzaj sumienia (przed-uczynkowe) jest dla lekarzy i personelu medycznego powołującego się na klauzulę sumienia bardzo ważny. Zaś sumienie po-uczynkowe ocenia to, co już zrobiliśmy, często wydając negatywne oceny, stąd można tu mówić o tzw. wyrzutach sumienia. Kolejno referent przywoływał przepisy prawne i dokonał ich krótkiej analizy. Wspomniał m.in. art. 30, art. 31 ust. 3 oraz art. 53 ust. 1 Konstytucji RP z 1997 r.; art. 9 ust. 1 Europejskiej Konwencji o Ochronie Praw Człowieka i Podstawowych Wolności z 1950 r.; art. 10 ust. 2 Karty Praw Podstawowych z 2000 r.; oraz ustawy dotyczące personelu medycznego, i ich prawa powołania się na klauzulę sumienia (ustawa $\mathrm{z}$ dnia 5 grudnia 1996 r. o zawodach lekarza i lekarza dentysty; ustawa z dnia 15 lipca 2011 r. o zawodach pielęgniarki i położnej).

Ostatni referat części pierwszej, zatytułowany Klauzula sumienia $w$ medycynie, wygłosili: ks. prof. Andrzej Derdziuk (KUL), prorektor KUL, kierownik Katedry Historii Teologii Moralnej, oraz dr Piotr Klimas, ginekolog-położnik ze szpitala św. Rodziny w Warszawie. W swoim wystąpieniu pierwszy z prelegentów stwierdził, że sumienie jest obiektywizowane przez prawo moralne. Szerzej rozwinął zagadnienia związane $\mathrm{z}$ procedurami medycznymi akceptowanymi w przyjętym w państwie 
systemie prawnym. Określił je jako liberty right i claim right (procedury, które można świadczyć pacjentowi i procedury, które koniecznie trzeba mu świadczyć). Kończąc swoje wystąpienie wyraził pogląd, że klauzula sumienia jest jednym z podstawowych praw pracowników służby zdrowia. Drugi z prelegentów, powołując się na przysięgę Hipokratesa, przyrzeczenie lekarskie i Kodeks Etyki Lekarskiej stwierdził, że lekarz nie może działać w sprzeczności ze swoim powołaniem, czyli ratowaniem życia i zdrowia pacjenta.

Druga część konferencji dotyczyła prezentacji Stanowiska Zespołu Ekspertów Konferencji Episkopatu Polski ds. Bioetycznych z dnia 14 lutego 2014 r. w sprawie klauzuli sumienia. Głos zabrali w kolejności: abp Henryk Hoser, prof. Zbigniew Cieślak oraz dr Piotr Klimas. W swoich wystąpieniach prezentowali wyżej wspomniany dokument od strony jego treści i struktury. Wszyscy podkreślali jego ważność jako głos Kościoła katolickiego w odpowiedzi na stanowisko Komitetu Bioetyki przy Prezydium PAN. Podsumowaniem konferencji były pytania z sali i dyskusja. Całość Konferencji podsumował pan Marcin Przeciszewski dziękując prelegentom za twórcze wystąpienia, a wszystkim za liczny udział.

Ks. mgr lic. Michat Czelny Wydziat Prawa, Prawa Kanonicznego i Administracji Katolicki Uniwersytet Lubelski Jana Pawła II

Sympozjum naukowe pt. Prawo matżeńskie Kościotów chrześcijańskich w Polsce $w$ kontekście wyznaniowej formy matżeństwa cywilnego, Warszawa, 26 marca 2014 r.

W dniu 26 marca 2014 r. w Chrześcijańskiej Akademii Teologicznej w Warszawie odbyło się sympozjum naukowe pt. Prawo matżeńskie Kościołów chrześcijańskich $w$ Polsce $w$ kontekście wyznaniowej formy małżeństwa cywilnego. Organizatorem wydarzenia była Katedra Prawa Wyznaniowego i Kanonicznego ChAT, a honorowy patronat nad nim objęli Minister Administracji i Cyfryzacji oraz Minister Spraw Wewnętrznych. Zdaniem organizatorów, za potrzebą podjęcia przedmiotowej problematyki przemawiała stosunkowo słaba znajomość małżeńskiego prawa kanonicz- 